\title{
Preferential prey selection by Desmodus rotundus (E. Geoffroy, 1810, Chiroptera, Phyllostomidae) feeding on domestic herbivores in the municipality of São Pedro - SP
}

\author{
Mialhe, PJ. ${ }^{a *}$ \\ a Laboratório de Análise e Planejamento Ambiental - LAPA, Universidade Federal de São Carlos - UFSCar, \\ Campus São Carlos, Rodovia Washington Luis, Km 235, CP 676, CEP 13565-905, São Carlos, SP, Brazil \\ *e-mail: paulomialhe@gmail.com
}

Received: August 27, 2012 - Accepted: April 19, 2013 - Distributed: August 31, 2014

\begin{abstract}
In order to verify possible preferential prey selection by Desmodus rotundus feeding on domestic herbivores in the Municipality of São Pedro (São Paulo, Brazil), vampire bat attacks were surveyed at rural properties where domestic herbivores were being raised and attack frequencies of $D$. rotundus on the total herd and on different species were calculated. The analysis found that the most frequently attacked herbivores were cattle and horses. The chi-square test $\left(\chi^{2}\right)$, with a significance level of $5 \%$ corroborated the comparative analysis of attack frequency in properties that had these two species. Of the two, horses were attacked more frequently, which could be a sign that $D$. rotundus exhibits preferential prey selection when attacking domestic herbivores. This evidence is also supported by the Optimal Foraging Theory, in which the net rate of energy consumed is higher for horses than it is for cattle. Additionally, we propose that the thinner integument of horses (relative to that of cattle) may facilitate bites by $D$. rotundus and thus contribute to the observed prey preference.
\end{abstract}

Keywords: cattle, horse, optimal foraging, vampire bat.

\section{Seleção de presas preferenciais por Desmodus rotundus (E. Geoffroy, 1810, Chiroptera, Phyllostomidae) alimentando-se de herbívoros domésticos no município de São Pedro - SP.}

\begin{abstract}
Resumo
A fim de verificar possível seleção de presa preferencial por Desmodus rotundus alimentando-se em herbívoros domésticos no Município de São Pedro (São Paulo, Brasil), foram pesquisados ataques de morcegos hematófagos em propriedades rurais nas quais os herbívoros domésticos estavam sendo criados e foram calculadas as frequências de ataques por D. rotundus no rebanho total e nas diferentes espécies. A análise mostrou que os herbívoros mais frequentemente atacados eram os bovinos e equinos. O teste do qui-quadrado $\left(\chi^{2}\right)$ com um nível de significância de $5 \%$ corroborou a análise comparativa da frequência de ataque em propriedades que possuíam estas duas espécies. Destas duas, os cavalos foram atacados com maior frequência, o que poderia ser um sinal de que $D$. rotundus apresenta seleção de presas preferenciais ao atacar herbívoros domésticos. Esta evidência também é apoiada pela Teoria do Forrageamento Ótimo, em que a taxa de energia líquida consumida é maior para cavalos do que para o gado. Além disso, propomos que o tegumento mais fino de cavalos (em relação à de bovinos) pode facilitar a mordidas por D. rotundus e, assim, contribuir para a preferência da presa observada.
\end{abstract}

Palavras-chave: bovinos, equinos, forrageamento ótimo, morcego hematófago.

\section{Introduction}

The vampire bats belong to the order Chiroptera, family Phyllostomidae, subfamily Desmodontinae. The family Phyllostomidae is an endemic clade to the New World, widely distributed from the Southwest of the United States of America (Hall, 1981; Patten, 2004) to the North of Argentina (Barquez et. al., 1999; Reis et al., 2007).

The bats belonging to the subfamily Desmodontinae are distinguished from other species of Neotropical bats by the rudimentary nature of the nose-leaf, the lack of a tail, and a reduced uropatagium. Additionally, the limbs are sturdy and well developed and the thumbs are elongated. These adaptations are related to the quadrupedal locomotor ability of Desmodus during walking, jumping and climbing. (Altenbach, 1979; Greenhall et al., 1983; Riskin et al., 2006).

The Desmodontinae includes three genera: Desmodus, Diaemus and Diphylla; and three hematophagous, sympatric and monotypic species: Desmodus rotundus, Diaemus 
youngii and Diphylla ecaudata. D. rotundus feeds on a wide range of prey, because this species is far more generalist than the other two vampire species (Gardner, 1977; Costa and Esbérard, 2011)

Desmodus rotundus is a strictly hematophagous species (Gardner, 1977; Brass, 1994; Mayen, 2003), being considered a predator and also a classical obligate parasite (Turner, 1975). Survival and reproduction of all animals are only possible when there is availability of usable energy. For predators to capture the largest number of prey, they have developed specific strategies. The set of strategies used by an individual to find, capture, subdue, swallow and counteract the defense mechanisms developed by the prey is named "foraging" (Pough et al. 2003).

In foraging activity, when potential prey are identified, predators need to make decisions. These decisions can be analysed by humans in terms of costs and benefits, and it takes into account physiological aspects (hunger, satiation and energy cost) and environmental aspects (presence or absence of potential predators and habitat quality, which is ascertained according to the available quantity of prey) (Chaves and Alves, 2010).

For the appropriate measure of "efficiency" on foraging behaviour, the net rate of consumed energy is generally employed - i.e., the amount of energy obtained per time unit, after having considered the energy used by the predator in the foraging activity. The expression optimal foraging is used for behavioural patterns that have been particularly favoured by natural selection, and it is admitted that they have been favoured due to yielding the highest net rate on energy gain (Townsend et al., 2006).

The diet amplitude is one of the categories of analysis of Optimal Foraging Theory, once it considers the variation range of food types consumed by a predator. To obtain food, any predator must have time and energy costs: firstly in the search for prey, and, afterwards, in prey manipulation (that is, chasing, subjugation and ingestion). During the search, a predator is likely to find a wide variety of food items. Diet amplitude, therefore, depends on the predator response, once they have found their prey. The generalists, those with broad diet, chase a large proportion of types of prey they find. Specialists, those with a strict diet, continue the search until they find their preferential prey (Townsend et al., 2006).

MacArthur and Pianka (1966) were concerned with the breadth of diet that natural selection could favour if the animal were optimally fed. Their basic approach for optimum use of time and energy relates to a higher net energy gain on foraging activity. Certain food types have lower capture and consumption costs than others, regarding gained food energy. Thus, such food items can be ranked from most to least fruitful, according to the net energy return they provide. The optimal foraging theory proposes the possibility of a forager to learn (by trial and error) which type of food is more difficult to be found and handled. It is considered that during the search for food, prey species are discovered in the proportion as they occur. Valuable items are always included in the animal's diet when found, as the least valuable items will be included or excluded from the diet, according to the variation of valuable prey availability (Turner, 1975; Townsend et al., 2006).

Variables of the optimal foraging theory, related to the predator investment in searching and handling the prey, can be represented by the following symbols: s1, search time for the most valuable prey; h1, handling time for the most valuable prey; and E1, energy content of the most valuable prey. Handling time for the least fruitful prey is h2, and its energy content is E2. The most valuable prey (E1), once found, will always be included in the predator's diet. However, the least valuable prey will only be included in the animal's diet if the most valuable prey is scarce, and the search time is too long. This can be represented by the equation $\mathrm{E} 2 / \mathrm{h} 2 \geq \mathrm{E} 1 /(\mathrm{s} 1+\mathrm{h} 1)(\mathrm{Krebs}$, 1996; Townsend et al., 2006).

MacArthur and Pianka (1966) and Emlen (1966) predicted that animals will be more selective in their diets when food is common and less selective when food is rare. The behaviour of $D$. rotundus seems to support this prediction. D. rotundus does not only select domestic hosts over wild hosts. It also prefers particular types of cattle breeds, particular age and sex class, and individuals in a particular reproductive status (Turner, 1975; Voigt and Kelm, 2006; Bobrowiec, 2008).

In this sense, are the bats actually selecting or preferring one type of prey over another, or are they merely feeding of available animals only (the ones that are exposed)? A number of observations point to a process of preference or selection. Greenhall (1972) observed that when a variety of hosts is present, the vampire bat is selective; although, when only the least preferred host is available, vampire bats may attack them severely (Turner, 1975; Voigt and Kelm, 2006).

Based on these premises, the present study aims to provide information on the foraging behaviour of Desmodus rotundus.

\section{Material and Methods}

\subsection{Study area}

This study was conducted during 2002 in the rural zone of the Municipality of São Pedro, state of São Paulo, located at a longitude of $47^{\circ} 45^{\prime} 00^{\prime \prime}$ 'West and latitude $22^{\circ} 42^{\prime} 00^{\prime \prime}$ South, in an area of approximately 62,000 ha, with altitudes ranging between 450 and 900 metres. The hydrography of this municipality is composed of the Piracicaba river, which forms the southern border with the Municipality of Piracicaba, in addition to the Pinheiros and Espraiado streams, and the small Samambaia river.

\subsection{Data collection and analysis}

We have researched all rural properties where domestic herbivores were raised (cattle, horse, pig, goat and sheep) in the Municipality of São Pedro - SP, totalling 80 properties. Interviews were performed with employees or proprietors of these farms, for collection of data about the number 
and species of animals present at the properties and the number of attacked animals.

After data collection, the attack frequency of $D$. rotundus was calculated, considering the total herd and the different domestic herbivore species. Based on the frequency data, it was possible to verify which species were attacked more often. After that, we compared the attack frequencies in properties where there were two of the most often attacked species, in order to confirm that there was some attack preference of $D$. rotundus for these species. For this analysis to be carried out, the chi-square test was performed, which is a measure of discrepancy between observed and expected frequencies, with a significance level of $5 \%$.

\section{Results}

Registration of properties, composition of the exposed herd and number of attacked animals are evidenced in Table 1 .

The total herd of the municipality was 12,685 animals: $89.98 \%$ were cattle (11,414 animals), $4.78 \%$ were horses (607), $4.35 \%$ were pigs (552), and $0.88 \%$ were small ruminants (111 sheep and one goat).

Table 1. Registration of properties, composition of the exposed herd and number of attacked animals. ID = property identification, $\mathrm{EC}=$ existing cattle, $\mathrm{AC}=$ attacked cattle, $\mathrm{EH}=$ existing horses, $\mathrm{AH}=$ attacked horses, $\mathrm{EP}=$ existing pigs, $\mathrm{AP}$ $=$ attacked pigs, $\mathrm{ESG}=$ existing sheep and goats, $\mathrm{ASG}=$ attacked sheep and goats, $\mathrm{TEA}=$ total exposed animals, TAA $=$ total attacked animals.

\begin{tabular}{|c|c|c|c|c|c|c|c|c|c|c|c|}
\hline PROPERTY & ID & EC & $\mathbf{A C}$ & EH & AH & EP & AP & ESG & ASG & TEA & TAA \\
\hline FZ STA MARIA R. P. MEIO & 1 & 1335 & 60 & 22 & 4 & 0 & 0 & 0 & 0 & 1357 & 64 \\
\hline HARAS RAMOS & 2 & 31 & 0 & 23 & 1 & 0 & 0 & 0 & 0 & 54 & 1 \\
\hline SITIO RANCHO FUNDO & 3 & 68 & 18 & 13 & 8 & 0 & 0 & 0 & 0 & 81 & 26 \\
\hline RANCHO KAJUBA & 4 & 0 & 0 & 80 & 10 & 0 & 0 & 0 & 0 & 80 & 10 \\
\hline HARAS AQUAM & 5 & 0 & 0 & 9 & 3 & 0 & 0 & 0 & 0 & 9 & 3 \\
\hline ANDRE ROCHA & 6 & 15 & 1 & 2 & 0 & 0 & 0 & 0 & 0 & 17 & 1 \\
\hline SITIO BEBEDOURO & 7 & 0 & 0 & 6 & 2 & 0 & 0 & 0 & 0 & 6 & 2 \\
\hline CHACARA BENEVIDES & 8 & 50 & 3 & 10 & 1 & 0 & 0 & 0 & 0 & 60 & 4 \\
\hline CHACARA GRAMINHA & 9 & 0 & 0 & 1 & 1 & 0 & 0 & 0 & 0 & 1 & 1 \\
\hline HARAS TUNCUM & 10 & 25 & 0 & 10 & 2 & 0 & 0 & 0 & 0 & 35 & 2 \\
\hline FZ BOA ESPERANÇA & 11 & 650 & 20 & 17 & 8 & 0 & 0 & 0 & 0 & 667 & 28 \\
\hline HARAS S. JOSE DAS AGUAS & 12 & 12 & 2 & 30 & 2 & 0 & 0 & 16 & 0 & 58 & 4 \\
\hline RECANTO DOS PASSAROS & 13 & 7 & 0 & 1 & 1 & 0 & 0 & 0 & 0 & 8 & 1 \\
\hline FZ RETIRO DO ARAQUA & 14 & 350 & 0 & 8 & 2 & 3 & 0 & 0 & 0 & 361 & 2 \\
\hline FZ STA RITA & 15 & 530 & 15 & 10 & 5 & 0 & 0 & 0 & 0 & 540 & 20 \\
\hline FZ STA ISABEL & 16 & 400 & 3 & 9 & 3 & 3 & 0 & 0 & 0 & 409 & 6 \\
\hline CH. RANCHO FUNDO & 17 & 0 & 0 & 1 & 1 & 0 & 0 & 0 & 0 & 1 & 1 \\
\hline SITIO BOA VISTA & 18 & 20 & 4 & 2 & 1 & 0 & 0 & 0 & 0 & 22 & 5 \\
\hline SITIO STO ANTONIO & 19 & 0 & 0 & 19 & 13 & 0 & 0 & 0 & 0 & 19 & 13 \\
\hline SITIO BELA VISTA & 20 & 50 & 0 & 3 & 1 & 3 & 0 & 0 & 0 & 56 & 1 \\
\hline SITIO JACAREPUPIRA & 21 & 0 & 0 & 3 & 3 & 1 & 0 & 0 & 0 & 4 & 3 \\
\hline SITIO JACAREPUPIRA & 22 & 6 & 2 & 0 & 0 & 0 & 0 & 0 & 0 & 6 & 2 \\
\hline SITIO JACAREPUPIRA & 23 & 20 & 0 & 1 & 1 & 0 & 0 & 0 & 0 & 21 & 1 \\
\hline SITIO S. JOAO & 24 & 25 & 2 & 4 & 1 & 0 & 0 & 0 & 0 & 29 & 3 \\
\hline SITIO JACAREPUPIRA & 25 & 26 & 2 & 2 & 2 & 10 & 2 & 0 & 0 & 38 & 6 \\
\hline FZ N. SRA DE FATIMA & 26 & 150 & 0 & 10 & 5 & 10 & 0 & 0 & 0 & 170 & 5 \\
\hline FZ STA NEUZA & 27 & 138 & 0 & 9 & 4 & 15 & 0 & 0 & 0 & 95 & 4 \\
\hline SITIO STA OLINA & 28 & 25 & 0 & 10 & 3 & 60 & 0 & 0 & 0 & 95 & 3 \\
\hline SITIO STA EOLINA & 29 & 20 & 0 & 2 & 1 & 0 & 0 & 0 & 0 & 22 & 1 \\
\hline FZ BELA VISTA & 30 & 40 & 0 & 3 & 1 & 1 & 0 & 0 & 0 & 43 & 1 \\
\hline HARAS AREIÃO & 31 & 100 & 0 & 30 & 1 & 0 & 0 & 0 & 0 & 130 & 1 \\
\hline SITIO VO PAULIQUINHO & 32 & 59 & 0 & 6 & 1 & 16 & 0 & 0 & 0 & 81 & 1 \\
\hline DIMAS DOMENICO & 33 & 0 & 0 & 1 & 1 & 0 & 0 & 0 & 0 & 1 & 1 \\
\hline RECANTO DAS SERIEMAS & 34 & 21 & 5 & 3 & 2 & 0 & 0 & 0 & 0 & 24 & 7 \\
\hline SITIO BONFIM & 35 & 30 & 0 & 1 & 1 & 0 & 0 & 0 & 0 & 31 & 1 \\
\hline AGRICOLA BELA VISTA & 36 & 1220 & 4 & 23 & 0 & 30 & 0 & 0 & 0 & 1273 & 4 \\
\hline FZ PAIOL DE TELHA & 37 & 200 & 0 & 9 & 3 & 150 & 0 & 25 & 0 & 384 & 3 \\
\hline
\end{tabular}


Table 1. Continued...

\begin{tabular}{|c|c|c|c|c|c|c|c|c|c|c|c|}
\hline PROPERTY & ID & EC & $\mathbf{A C}$ & EH & $\mathbf{A H}$ & EP & AP & ESG & ASG & TEA & TAA \\
\hline SITIO BEBEDOURO & 38 & 42 & 2 & 0 & 0 & 0 & 0 & 0 & 0 & 42 & 2 \\
\hline SITIO PAIOL DE TELHA & 39 & 10 & 0 & 4 & 1 & 1 & 0 & 0 & 0 & 15 & 1 \\
\hline FZ PALMEIRAS & 40 & 130 & 0 & 7 & 3 & 0 & 0 & 0 & 0 & 137 & 3 \\
\hline CH. N. SRA. DAS GRAÇAS & 41 & 4 & 1 & 2 & 2 & 0 & 0 & 0 & 0 & 6 & 3 \\
\hline ENGENHO S. PEDRO & 42 & 1226 & 2 & 23 & 1 & 40 & 0 & 0 & 0 & 1289 & 3 \\
\hline SITIO BICUDO & 43 & 73 & 3 & 6 & 4 & 14 & 0 & 0 & 0 & 93 & 7 \\
\hline FZ STA BARBARA & 44 & 140 & 15 & 3 & 0 & 20 & 0 & 0 & 0 & 163 & 15 \\
\hline SITIO GRAMINHA & 45 & 20 & 1 & 2 & 0 & 9 & 0 & 0 & 0 & 31 & 1 \\
\hline HARAS PARAISO & 46 & 10 & 0 & 19 & 1 & 0 & 0 & 0 & 0 & 29 & 1 \\
\hline FZ S. JOSE & 47 & 8 & 0 & 5 & 2 & 0 & 0 & 0 & 0 & 13 & 2 \\
\hline SITIO STO ANTONIO & 48 & 26 & 4 & 0 & 0 & 0 & 0 & 0 & 0 & 26 & 4 \\
\hline SITIO NASCENTE DA SERRA & 49 & 10 & 1 & 2 & 1 & 0 & 0 & 14 & 0 & 181 & 2 \\
\hline SI, STO ANTONIO DE PADUA & 50 & 25 & 0 & 2 & 1 & 0 & 0 & 0 & 0 & 27 & 1 \\
\hline SITIO N. SRA. APARECIDA & 51 & 55 & 0 & 4 & 1 & 30 & 0 & 2 & 0 & 91 & 1 \\
\hline SITIO S. BENTO & 52 & 42 & 4 & 1 & 0 & 9 & 3 & 0 & 0 & 52 & 7 \\
\hline RANCHO S. PEDRO & 53 & 2 & 1 & 0 & 0 & 0 & 0 & 0 & 0 & 2 & 1 \\
\hline FZ DA BARRA & 54 & 260 & 120 & 10 & 5 & 7 & 3 & 0 & 0 & 277 & 128 \\
\hline FZ STA ISABEL & 55 & 36 & 2 & 0 & 0 & 0 & 0 & 0 & 0 & 26 & 2 \\
\hline SITIO ANA ADRIANA & 56 & 55 & 0 & 7 & 3 & 4 & 2 & 1 & 0 & 67 & 5 \\
\hline SITO STA LUZIA & 57 & 0 & 0 & 2 & 2 & 8 & 0 & 0 & 0 & 10 & 2 \\
\hline CH. S. JOAO & 58 & 2 & 0 & 9 & 8 & 11 & 0 & 0 & 0 & 22 & 8 \\
\hline RUA 6 & 59 & 0 & 0 & 7 & 1 & 0 & 0 & 0 & 0 & 7 & 1 \\
\hline RUA 4 & 60 & 0 & 0 & 2 & 2 & 0 & 0 & 0 & 0 & 2 & 2 \\
\hline FZ MONTE LIBANO & 61 & 450 & 0 & 4 & 1 & 0 & 0 & 20 & 0 & 474 & 1 \\
\hline FZ STA HELENA & 62 & 900 & 4 & 12 & 4 & 0 & 0 & 9 & 0 & 921 & 8 \\
\hline FZ BELO HORIZONTE & 63 & 230 & 0 & 12 & 2 & 4 & 0 & 25 & 0 & 271 & 2 \\
\hline SITIO STA ISABEL & 64 & 80 & 2 & 1 & 1 & 8 & 3 & 0 & 0 & 89 & 6 \\
\hline SITIO S. SEBASTIÃO & 65 & 120 & 1 & 1 & 1 & 15 & 0 & 0 & 0 & 135 & 2 \\
\hline CH. BOA VISTA & 66 & 0 & 0 & 3 & 2 & 24 & 0 & 0 & 0 & 27 & 2 \\
\hline FZ AURORA & 67 & 176 & 5 & 5 & 5 & 0 & 0 & 0 & 0 & 181 & 10 \\
\hline FZ MONJOLINHO & 68 & 180 & 3 & 3 & 0 & 0 & 0 & 0 & 0 & 183 & 3 \\
\hline SITIO TORRÃO DE OURO & 69 & 40 & 1 & 2 & 0 & 3 & 0 & 0 & 0 & 45 & 1 \\
\hline FAZENDINHA & 70 & 80 & 5 & 5 & 2 & 0 & 0 & 0 & 0 & 85 & 7 \\
\hline SITIO JACAREPUPIRA & 71 & 20 & 3 & 2 & 2 & 12 & 0 & 0 & 0 & 34 & 5 \\
\hline CHACARA 3 IRMÃOS & 72 & 1 & 1 & 2 & 2 & 20 & 0 & 0 & 0 & 23 & 3 \\
\hline SITIO AGUA BRANCA & 73 & 35 & 3 & 2 & 0 & 1 & 0 & 0 & 0 & 38 & 3 \\
\hline FZ FLORESTAL & 74 & 0 & 0 & 2 & 2 & 0 & 0 & 0 & 0 & 2 & 2 \\
\hline FZ S. SEBASTIÃO & 75 & 200 & 6 & 6 & 1 & 0 & 0 & 0 & 0 & 206 & 7 \\
\hline PEDRO BRAGANHOLO & 76 & 34 & 0 & 3 & 3 & 10 & 0 & 0 & 0 & 47 & 3 \\
\hline FZ ARAQUA & 77 & 1000 & 10 & 25 & 5 & 0 & 0 & 0 & 0 & 1025 & 15 \\
\hline SITIO PIO XII & 78 & 40 & 2 & 1 & 1 & 0 & 0 & 0 & 0 & 41 & 3 \\
\hline ESTANCIA VALE VERDE & 79 & 0 & 0 & 2 & 1 & 0 & 0 & 0 & 0 & 2 & 1 \\
\hline FZ NOVA PRAINHA & 80 & 29 & 0 & 4 & 2 & 0 & 0 & 0 & 0 & 33 & 2 \\
\hline TOTAL & --- & 11414 & 343 & 607 & 174 & 552 & 13 & 112 & 0 & 12685 & 530 \\
\hline
\end{tabular}

During our study, we verified that 530 animals were attacked, or $4.18 \%$ of the entire herd. There was no record of attacks on small ruminants. The cattle species showed the highest number of attacked animals (343), followed by horses (174) and pigs (13), representing, respectively, $64.47 \%, 32.83 \%$ and $2.44 \%$ of the total logged attacks.
By calculating the attack percentage of Desmodus rotundus on each individual herd (cattle, horse, pig and small ruminants), we determined that horses suffered the highest percentage of attacks, with $28.66 \%$ of the herd attacked, followed by cattle, with $3.00 \%$ and pigs, with $2.35 \%$. These data are summarised in Table 2 . 
Table 2. Percentage of attacked animals for each species' herd. NAH = Number of animals of the herd; NAA = Number of attacked animals; PAASH $=$ Percentage of attacked animals in its species' herd.

\begin{tabular}{lccc}
\hline \multicolumn{1}{c}{ SPECIES } & NAH & NAA & PAASH \\
\hline Cattle & 11,414 & 343 & 3 \\
Horse & 607 & 174 & 28.66 \\
Pig & 552 & 13 & 2.35 \\
Small ruminants & 112 & 0 & 0 \\
Total & 12685 & 530 & ----------- \\
\hline
\end{tabular}

Table 3. Normal levels of glucose in blood, plasma or serum, of cattle and horse (Coles, 1984).

\begin{tabular}{cccc}
\hline SPECIES & SAMPLES & LEVEL mg/dl & METHOD \\
\hline CATTLE & Plasma or serum & $45-70$ & Somogyi \\
& Blood & $53.2+/-8.3$ & Glucose-oxidase \\
\multirow{2}{*}{ HORSE } & Plasma & $72.3+/-6.9$ & Glucose-oxidase \\
& Plasma or serum & $66-100$ & Somogyi \\
& Blood & $61.1+/-6.7$ & Glucose-oxidase \\
& Plasma & $83.5+/-4.7$ & Glucose-oxidase \\
\hline
\end{tabular}

Table 4. Normal levels of glucose in blood of cattle and horse. Method Enzimatic Automated (Kaneko et al., 2008).

\begin{tabular}{lcc}
\multicolumn{1}{c}{ SPECIES } & SAMPLES & LEVEL $\mathbf{~ m g / d l}$ \\
\hline CATTLE & Blood & $45-75$ \\
HORSE & Blood & $75-115$ \\
\hline
\end{tabular}

Data from Table 2 showed that the population of D. rotundus in the Municipality of São Pedro - SP presented a preference of foraging for horses, because there was significant discrepancy between the expected and the observed attack frequency on equine and bovine herds, which was proven by applying the chi-square test $(\mathrm{p}<0.05)$.

In order to verify whether this preference could be explained through the Optimal Foraging Theory, we have compared the energy values (E) and handling time (h) for the two most often attacked species. In order to compare the energy values of prey, we have used the normal levels of glucose on blood of cattle and horse, as described in Table 3 and 4 . In order to compare the handling time of prey (h), we have verified the thickness of cattle and horses integument, because a thinner integument would facilitate the incision of Desmodus rotundus, thus reducing the prey handling time.

The thickness of the horse integument varies between 1 and $5 \mathrm{~mm}$ on different body areas, being thicker upon the insertion of the mane and the dorsal surface of the tail. The thickness of bovine integument is higher than of any other domestic animals; it generally has between 3 and $4 \mathrm{~mm}$, reaching $5 \mathrm{~mm}$ at the base of the tail and the tip of the hock, and between 6 and $7 \mathrm{~mm}$ at chest height (Getty, 2008).

\section{Discussion}

The low rate of attacks on pigs and the absence of attacks on sheep and goats is not an unexpected finding. Turner (1975), in his studies in Costa Rica, reports that, although sheeps and pigs are occasionally attacked by vampire bats, the frequency is sufficiently low for excluding these domestic animals from his examinations. The vampire bats in Costa Rica have primarily attacked cattle and horses, as it was found in our study.

It has been frequently supposed that vampire bats have nowadays a richer supply of blood from domestic animals than autochthonous wild life would have provided them (Dalquest, 1955; Greenhall, 1968; Costa and Esbérard, 2011). The theoretical model here discussed predicts that the higher the absolute abundance of food, the narrower the range of diet items. In other words, the greater the availability of food, the greater the predator selectivity. Therefore, if $D$. rotundus can be seen as highly selective with various types of domestic animal herds, predictions of the foraging model can be maintained (Turner, 1975). This author reports that, in his research in Costa Rica, horses were the most attacked species; however, a total population of 30 to 35 horses was insufficient for serving as focus for his 15-month study. This way, he chose the large cattle population in order to evaluate prey preferences of the vampire bat and the potential bases for these preferences, such as age, sex, reproductive status and location of the prey in the herd.

In the Municipality of São Pedro, 12 out of the 80 researched properties had only horses, and five had only cattle; the remaining 63 had both. This implies that at these 63 properties, both herds represented the same search time (s1) for D. rotundus, because they are within the same distance from the bat shelter. By analysing the attack frequency on cattle and horse, it is possible to verify a higher attack percentage on horses in 54 out of the 63 properties - that represents $85.71 \%$ of the properties in which cattle and horses are raised; the number of logged attacks on horses was proportionally higher.

Using MacArthur and Pianka's (1966) Optimal Foraging Theory, and comparing energy values (E) and handling 
time (h) for each species, it is possible to notice that the energy value of horse blood is higher than it is for cattle blood, because it presents higher blood glucose (Tables 3 and 4). For D. rotundus, the handling of equines appears to be simpler, due to the lower thickness of the horse integument, in comparison to cattle integument, which may facilitate the incision of the bat. Dalquest (1955) and Linhart, Crespo and Mitchell (1972) have also discovered that vampire bats in Mexico prefer calves to adult cattle; skin thickness may influence this preference (Turner, 1975).

Handling of beef cattle, hampers the detection of wounds caused by $D$. rotundus (for being performed in an extensive form), because the cattle stays most of the time in the pasture, away from direct contact with handlers or the owner. By the fact that the herd of the Municipality of São Pedro is composed of $90 \%$ cattle, and due to the extensive breeding system, detected attacks of $D$. rotundus on beef cattle may have been underestimated by handlers; the total attacks percentage on the cattle herd could exceed 3\%. However, even if this possibility is considered, the attack frequency is much lower than the $28.66 \%$ reported for the equine herd. Further studies are suggested, under controlled conditions, in order to obtain a better understanding of the foraging behaviour of $D$. rotundus, including evidence of the bat's preferential prey among domestic herbivores.

\section{References}

ALTENBACH, JS., 1979. Locomotor morphology of the vampire bat Desmodusrotundus. New Mexico: American Society of Mammalogists. p. 1-137. Special Publications, vol. 6.. http:// dx.doi.org/10.5962/bhl.title.39538.

BARQUEZ, RM., MARES, MA. and BRAUN, JK., 1999. The bats of Argentina. Lubbock: Museum Texas Tech University. p. 1-275. Special Publications, vol. 42.

BRASS, DA., 1994. Rabies in bats: natural history and public health implications. Ridgefield: Livia Press. 352 p.

BOBROWIEC, PED., 2008. Caracterização molecular da dieta do morcego hematófago Desmodusrotundus (Mammalia :Chiroptera) na Amazônia brasileira. Manaus: INPA/UFAM. Tese de Doutorado em Genética.

CHAVES, FG. and ALVES, MAS., 2010. Teoria do Forrageamento Ótimo: premissas e criticas em estudos com aves. Oecologia Australis, vol. 14, no. 2, p. 369-380. http://dx.doi.org/10.4257/ oeco.2010.1402.03.

COLES, EH., 1984. Patologia clínica veterinária. 3. ed. São Paulo: Manole.

COSTA, LM. and ESBÉRARD, CEL., 2011. Desmodus rotundus (Mammalia: Chiroptera) on the southern coast of Rio de Janeiro state, Brazil. Brazilian Journal of Biology, vol. 71, no. 3, p. 739-746. http://dx.doi.org/10.1590/S1519-69842011000400020. PMid:21881799

DALQUEST, WW., 1955. Natural history of the vampire bats of eastern Mexico. American Midland Naturalist, vol. 53, no. 1, p. 79-87. http://dx.doi.org/10.2307/2422300.

EMLEN, JM., 1966. The role of time and energy in food preference. American Naturalist, vol. 100, no. 916, p. 611-617. Available from: http://www.jstor.org/discover/10.2307/2459299?uid=2\& uid=4\&sid=21104391205307. http://dx.doi.org/10.1086/282455.
GARDNER, AL., 1977. Feeding habits. In BAKER, RJ., JONES JUNIOR, JK. and CARTER, DC. Biology of the bats of the New World family Phyllostomatidae. Lubbock: Museum Texas Tech University. 364 p. Special Publications, vol. 3.

GETTY, R., 2008. Anatomia dos animais domésticos. 5. ed. Rio de Janeiro: Guanabara.

GREENHALL, AM., 1968. Problems and ecological implications in the control of vampire bats. International Union for the Conservation of Nature Publications. New Series (Morges), vol. 13, p. 94-102.

GREENHALL, AM., 1972. The biting and feeding habits of the vampire bat, Desmodusrotundus. Journal of Zoology, vol. 168, no. 4 , p. 451-461.

GREENHALL, AM., JOERMANN, G., SCHMIDT, U. and SEIDEL, MR., 1983. Desmodusrotundus. Mammalian Species, vol. 202, no. 202, p. 1-6. http://dx.doi.org/10.2307/3503895.

HALL, ER., 1981. The mammals of North America. 2nd ed. New York: John Wiley \& Sons. 690 p.

KANEKO, JJ., HARVEY, JW. and BRUSS, ML., 2008. Clinical biochemistry of domestic animals. 6th ed. San Diego: Elsevier.

KREBS, JR., 1996. Introdução a ecologia comportamental. 3. ed. São Paulo: Atheneu.

LINHART, SB., CRESPO, RF. and MITCHELL, GC., 1972. Control of vampire bats by topical applicaton of an anticoagulant, chlorophacinone. Boletin de la Oficina Sanitaria Panamericana, vol. 6 , no. 2, p. 31-38.

MACARTHUR, RH. and PIANKA, ER., 1966. On optimal use of a patchy environment. American Naturalist, vol. 100, no. 916, p. 603-609. http://dx.doi.org/10.1086/282454

MAYEN, F., 2003. Haematophagous bats in Brazil, their role in rabies transmission, impact on public health, livestock industry and alternatives to an indiscriminate reduction of bat population. Journal of Veterinary Medicine, Series B, vol. 50, no. 10, p. 469-472. http://dx.doi.org/10.1046/j.1439-0450.2003.00713.x. PMid:14720182

PATTEN, MA., 2004. Correlates of species richness in North America bat families. Journal of Biogeography, vol. 31, no. 6, p. 975-985. http://dx.doi.org/10.1111/j.1365-2699.2004.01087.x.

POUGH, FH., HEISER, JB. and MCFARLAND,WN., 2003. A vida dos vertebrados. 3. ed. São Paulo: Atheneu.

REIS, NR., PERACCHI, AL., PEDRO, WA. and LIMA, IP., 2007. Morcegos do Brasil. Londrina. p. 39-43.

RISKIN, DK., PARSONS, S., SCHUTT, WA Jr., CARTER, GG. and HERMANSON, JW., 2006. Terrestrial locomotion of the New Zealand short-tailed bat Mystacina tuberculata and the common vampire bat Desmodus rotundus. The Journal of Experimental Biology, vol. 209, no. Pt 9, p. 1725-1736. http://dx.doi.org/10.1242/ jeb.02186. PMid:16621953

TOWNSEND, CR., BEGON, M. and HARPER, JL., 2006. Fundamentosemecologia. 2. ed. Porto Alegre: Artmed.

TURNER, DC., 1975. The vampire bat: a field study in behaviour and ecology. The Johns Hopkins University Press. 145 p.

VOIGT, CC. and KELM, DH., 2006. Host preference of the common vampire bat (Desmodusrotundus; Chiroptera) assessed by Stable isotopes. Journal of Mammalogy, vol. 87, no. 1, p. 1-6. http://dx.doi.org/10.1644/05-MAMM-F-276R1.1. 